\title{
Methylmercury Photodegradation in Surface Water of the Florida Everglades: Importance of Dissolved Organic Matter-Methylmercury Complexation
}

Chao Tai, ${ }^{\dagger, \S, \|, \nabla}$ Yanbin Li, ${ }^{\ddagger},, \|, \nabla$ Yongguang Yin, ${ }^{\perp, \S, \|}$ Leonard J. Scinto,, ${ }^{\#, \|}$ Guibin Jiang, ${ }^{\perp}$ and Yong $\mathrm{Cai}^{\S}, \|, *$

${ }^{\dagger}$ Institute of Resources and Environment, Henan Polytechnic University, Jiaozuo, 454000, China

${ }^{\ddagger}$ Key Laboratory of Marine Chemistry Theory and Technology, Ministry of Education, Ocean University of China, Qingdao, 266100, China

${ }^{\S}$ Department of Chemistry \& Biochemistry, Florida International University, Miami, Florida 33199, United States

"Southeast Environmental Research Center, Florida International University, Miami, Florida 33199, United States

${ }^{\perp}$ State Key Laboratory of Environmental Chemistry and Ecotoxicology, Research Center for Eco-Environmental Sciences, Chinese Academy of Sciences, Beijing, 100085, China

\# Department of Earth and Environment, Florida International University, Miami, Florida 33199, United States

\section{Supporting Information}

ABSTRACT: Photodegradation is the major pathway of methylmercury $(\mathrm{MeHg})$ degradation in many surface waters. However, the mechanism of $\mathrm{MeHg}$ photodegradation is still not completely understood. Dissolved organic matter (DOM) is expected to play a critical role in $\mathrm{MeHg}$ photodegradation. By using several techniques, including $\mathrm{N}_{2} / \mathrm{O}_{2}$ purging and the addition of stable isotope $\left(\mathrm{Me}^{201} \mathrm{Hg}\right)$, scavengers, competing ligands, and a singlet oxygen $\left({ }^{1} \mathrm{O}_{2}\right)$ generator, the role played by $\mathrm{MeHg}-\mathrm{DOM}$ complexation in $\mathrm{MeHg}$ photodegradation of Everglades surface water was investigated. DOM appeared to be involved in $\mathrm{MeHg}$ photodegradation via the formation $\mathrm{MeHg}-\mathrm{DOM}$ complexes based on three findings: (1) MeHg was quickly photodegraded in solutions containing DOM extracts; (2) degradation of MeHg did not occur in deionized water; and (3) addition of competing complexation reagents (dithiothreitol-DTT) dramatically prohibited the photodegradation of $\mathrm{MeHg}$ in Everglades water. Further experiments indicated that free radicals/reactive oxygen species, including hydroxyl radical $(\cdot \mathrm{OH}),{ }^{1} \mathrm{O}_{2}$, triplet excited state of DOM $\left({ }^{3} \mathrm{DOM}^{*}\right)$, and hydrated electron $\left(\mathrm{e}^{-}{ }_{\text {aq }}\right)$, played a minor role in $\mathrm{MeHg}$ photodegradation in Everglades water, based on the results of scavenger addition, ${ }^{1} \mathrm{O}_{2}$ generator addition and $\mathrm{N}_{2} / \mathrm{O}_{2}$ purging. A pathway, involving direct photodegradation of $\mathrm{MeHg}-\mathrm{DOM}$ complexes via intramolecular electron transfer, is proposed as the dominant mechanism for $\mathrm{MeHg}$ photodegradation in Everglades water.
Mechanism of MeHg photodegradation in the Florida Everglades

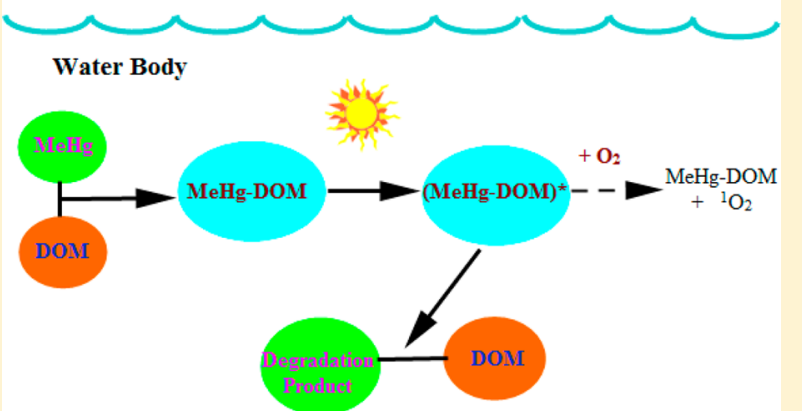

\section{INTRODUCTION}

Methylmercury $(\mathrm{MeHg})$ is the most notorious form of mercury in the environment, and has drawn public concern due to its toxicity, bioaccumulation, and biomagnification through food webs. ${ }^{1-3}$ In aquatic environments, $\mathrm{MeHg}$ is primarily formed by sulfate reducing bacteria ${ }^{4}$ or iron reducing bacteria ${ }^{5}$ in anoxic sediment, and sometimes by photomethylation in surface water. ${ }^{6}$ In addition to methylation, degradation of $\mathrm{MeHg}$ also plays an important role in the biogeochemical cycling of mercury in aquatic ecosystems. This process may occur through a number of abiotic or biotic pathways. ${ }^{7-9}$ Although microbial demethylation of $\mathrm{MeHg}$ was observed both in sediment ${ }^{10}$ and in the water column, ${ }^{11}$ most previous studies demonstrated that photodegradation is the major pathway of $\mathrm{MeHg}$ degradation in surface water. ${ }^{12-14}$ It was reported that photodegradation could remove a large proportion of the $\mathrm{MeHg}$ loading into lake water. ${ }^{15,16}$

Since its importance was demonstrated, ${ }^{14}$ several researchers have attempted to mechanistically determine the $\mathrm{MeHg}$ photodegradation process in aquatic environments. ${ }^{17-20}$ Although wavelength-specific photodegradation of $\mathrm{MeHg}$ has been observed in aquatic environments, ${ }^{13,21}$ much remains unclear about the chemical processes governing $\mathrm{MeHg}$ photodegradation. Previous reports suggest three potential pathways are responsible for $\mathrm{MeHg}$ photodegradation: (1)

Received: January 21, 2014

Revised: April 24, 2014

Accepted: June 5, 2014

Published: June 5, 2014 
direct photodegradation of $\mathrm{MeHg}^{18}$ (2) photodegradation of $\mathrm{MeHg}$-dissolved organic matter (DOM) complexes by free radicals/reactive oxygen species $\left({ }^{1} \mathrm{O}_{2}\right.$, triplet excited state of DOM $\left({ }^{3} \mathrm{DOM}^{*}\right)$, hydrated electron $\left(\mathrm{e}^{-} \mathrm{aq}\right)$, and $\left.\cdot \mathrm{OH}\right),{ }^{19}$ and (3) photodegradation of $\mathrm{MeHg}$ not complexed with DOM by free radicals/reactive oxygen species. ${ }^{20}$

Direct photodegradation of $\mathrm{MeHg}$ species such as $\mathrm{MeHgOH}$, and $\mathrm{MeHgCl}$ (pathway 1) $\left(\Delta E_{\mathrm{S}-\mathrm{T}}\right.$ (Singlet-triplet excitation energies) $5.1-5.9 \mathrm{eV}^{22}$ ) is theoretically difficult under solar radiation, as absorption by atmospheric ozone limits the solar spectrum at $4.4 \mathrm{eV}^{23}$ Most experiments also suggest that $\mathrm{MeHg}$ could not be photodegraded in deionized water (DI water). ${ }^{19,20}$ In the other two possible pathways (pathway 2 and 3), DOM could be involved because of its ability to produce free radicals/reactive oxygen species $\left({ }^{1} \mathrm{O}_{2},{ }^{24,25}\right.$ triplet excited state of DOM $\left({ }^{3} \mathrm{DOM}^{*}\right),{ }^{26,27}$ hydrated electron $\left(\mathrm{e}^{-}{ }_{\mathrm{aq}}\right),{ }^{28-30}$ and $\cdot \mathrm{OH}^{31,32}$ ) and to form $\mathrm{MeHg}-\mathrm{DOM}$ complexes. ${ }^{33}$ DOM should play a critical role in $\mathrm{MeHg}$ photodegradation. ${ }^{17,19}$ Recent studies have demonstrated quick photodegradation of $\mathrm{MeHg}$ in solutions prepared with DOM isolated from wetlands ${ }^{18}$ and rivers ${ }^{19}$ under solar radiation. However, other studies proposed that $\cdot \mathrm{OH}$ produced by the photo-Fenton reaction, without the involvement of DOM, could be the driver. ${ }^{20}$ In addition to the disagreement of the importance of DOM, there is also a controversy on which free radicals/ reactive oxygen species are involved in $\mathrm{MeHg}$ photodegradation. ${ }^{19,20}$

In most previous studies, ${ }^{1} \mathrm{O}_{2}$ or $\cdot \mathrm{OH}$ were speculated to be the free radicals/reactive oxygen species driving the photodegradation of $\mathrm{MeHg}{ }^{19,20}$ These conclusions were based mainly on the results of adding scavengers to remove various free radicals/reactive oxygen species ${ }^{18-20}$ or measuring the degradation of $\mathrm{MeHg}$ in the presence of simulated ${ }^{1} \mathrm{O}_{2}$ or $\cdot \mathrm{OH}$ generators. ${ }^{19,20}$ These studies had several obvious shortcomings. First, although ${ }^{1} \mathrm{O}_{2}$ or $\cdot \mathrm{OH}$ is commonly considered the free radicals/reactive oxygen species dominating $\mathrm{MeHg}$ photodegradation, none of these studies compared the difference of $\mathrm{MeHg}$ photodegradation under oxic and anoxic conditions, which is one of the important factors for confirming the importance of reactive oxygen species. ${ }^{34,35}$ Second, there is a lack of studies evaluating the importance of $\mathrm{e}^{-}$aq, which is believed to be involved in the photodegradation of many pollutants. ${ }^{29,30}$ Finally, although $\mathrm{MeHg}-\mathrm{DOM}$ complexation was speculated to be critical for $\mathrm{MeHg}$ photodegradation, ${ }^{19}$ there is a lack of evidence on the importance of this process in natural waters. In the past few years, several mechanisms have been proposed to drive the photodegradation of $\mathrm{MeHg}$ in surface waters, including ${ }^{1} \mathrm{O}_{2}$ induced degradation of $\mathrm{MeHg}-$ DOM complexes, ${ }^{19} \cdot \mathrm{OH}$ (generated by photo-Fenton reaction) induced photodegradation, ${ }^{20}$ and possible direct photodegradation. ${ }^{18}$ The inconsistent outcomes of previous studies, conducted in different aquatic systems, indicate that the mechanism of $\mathrm{MeHg}$ photodegradation is still not completely understood.

The Everglades is a subtropical wetland ecosystem located in South Florida. Extensive studies have been carried out to understand the cycling of mercury in this ecosystem over the last two decades. ${ }^{10,13,36-39}$ In our previous Everglades studies, photomethylation $^{40}$ and biotic degradation ${ }^{13}$ in surface water was found to play a minor role in the cycling of $\mathrm{MeHg}$. $\mathrm{MeHg}$ photodegradation was calculated to account for about $31 \%$ of the $\mathrm{MeHg}$ diffused from peat soils into the water column, ${ }^{13}$ indicating the importance of photodegradation in $\mathrm{MeHg}$ cycling. The major objective of this study was to elucidate the pathways of $\mathrm{MeHg}$ photodegradation in Everglades surface water. To achieve this objective, stable isotope $\left(\mathrm{Me}^{201} \mathrm{Hg}\right)$ addition technique was adopted to measure the rate of $\mathrm{MeHg}$ photodegradation under a variety of treatments. DOM extraction and competing ligand addition approaches were employed to test the importance of $\mathrm{MeHg}-\mathrm{DOM}$ complexes in $\mathrm{MeHg}$ photodegradation. Scavenger addition, ${ }^{1} \mathrm{O}_{2}$ generator addition and $\mathrm{N}_{2} / \mathrm{O}_{2}$ purge experiments were utilized to determine the importance of the free radicals/reactive oxygen species in $\mathrm{MeHg}$ photodegradation.

\section{MATERIALS AND METHODS}

Reagents. MeHg standard was purchased from Ultra Scientific (N. Kingstown, RI). Enriched ${ }^{201} \mathrm{HgO}$ and ${ }^{199} \mathrm{HgO}$ (isotope purity, $96.17 \pm 0.56 \%$, and $91.09 \pm 0.05 \%$, respectively) were purchased from Oak Ridge National Laboratory (Oak Ridge, Tennessee) and used to synthesize enriched $\mathrm{Me}^{201} \mathrm{Hg}$ and $\mathrm{Me}^{199} \mathrm{Hg}$ using the methylcobalamin method. ${ }^{13}$ Ultrahigh purity grade nitrogen and oxygen was used for degassing water. Other reagents used were of reagent or higher grade. Ultrapure water $(>18 \mathrm{M} \Omega-\mathrm{cm})$ was used to prepare all chemical solutions.

Measurement of MeHg Photodegradation Rate Constants under Various Treatments. Surface water was collected from the Everglades $\left(25^{\circ} 45^{\prime} \mathrm{N}, 80^{\circ} 44^{\prime} \mathrm{W}\right) 1$ day before photodegradation experiments. All experiments were conducted under ambient solar radiation at Florida International University $\left(25^{\circ} 45^{\prime} \mathrm{N}, 80^{\circ} 22^{\prime} \mathrm{W}\right)$, approximately $10 \mathrm{~km}$ from the sampling site. $\mathrm{Me}^{201} \mathrm{Hg}$ was spiked into $500 \mathrm{~mL}$ of unfiltered surface water or extracted DOM solution placed in $500 \mathrm{~mL}$ fluorinated ethylene propylene (FEP) bottles to a final concentration of $1.0 \mathrm{ng} \mathrm{L}{ }^{-1}$. Samples were then incubated under ambient solar radiation $\left(29.7-35.1 \mathrm{E} \mathrm{m}^{-2} \mathrm{~d}^{-1}\right.$, average $\left.32.4 \mathrm{E} \mathrm{m}^{-2} \mathrm{~d}^{-1}\right)$ and temperature $\left(20.0-31.9{ }^{\circ} \mathrm{C}\right.$, average 21.1 ${ }^{\circ} \mathrm{C}$ ) for 6 days. During the experiment, intensity of ambient PAR was measured at 15 min intervals routinely using LI-192 Quantum Sensor (LICOR Biosciences, Lincoln, Nebraska). Triplicates (three separate bottles) were employed for each trial. An aliquot of water $(35 \mathrm{~mL})$ was taken from each bottle after $0,1,2,4,6$ days of incubation. The aliquots were preserved to $1 \%$ concentrated $\mathrm{HCl}$ and then kept at $4{ }^{\circ} \mathrm{C}$ until analysis. $\mathrm{Me}^{201} \mathrm{Hg}$ in the water samples was analyzed to calculate $\mathrm{MeHg}$ photodegradation rate constants (See Data Analysis). Details for $\mathrm{Me}^{201} \mathrm{Hg}$ analysis can be found in the Supporting Information (SI).

Influence of DOM Isolated from Everglades Water and Various Complexing Ligands on MeHg Photodegradation. DOM (>3000 Da) was concentrated from filtered $(0.22 \mu \mathrm{m}$, PTFE) Everglades water using a cross-flow ultrafiltration technique with a $3000 \mathrm{Da}$ Millipore tangential flow filter membrane. The high molecular weight (HMW) DOM fraction was concentrated $\sim 25$ folds and washed 7 times with DI water to remove the low molecular weight (LMW) DOM and inorganic ions. Flocculation of DOM was not observed in HMW DOM when washing with DI water (possibly due to the near-neutral conditions, $\mathrm{pH} 6.7$ in the water samples). The filtrates composed of low molecular weight DOM and ions were named as LMW. Concentrations of DOM and various ions in HMW and LMW fractions, and in Everglades water are shown in SI Table S1. The HMW fraction DOM was diluted 25 times to its original concentration in Everglades water prior to experimentation. Photodegradation 

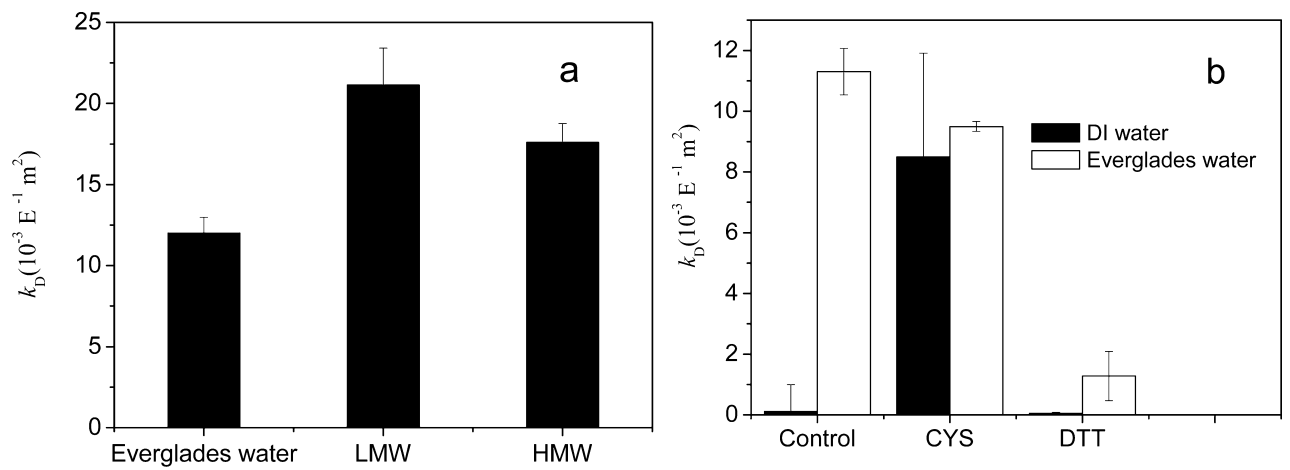

Figure 1. Importance of DOM- MeHg complexation in $\mathrm{MeHg}$ photodegradation. (a), $\mathrm{Me}{ }^{201} \mathrm{Hg}$ photodegradation rate constants in $>3000 \mathrm{Da} \mathrm{DOM}$ solution obtained from $>3000 \mathrm{Da}$ of Everglades water (HWM), Everglades water (control), and <3000 Da of Everglades water (LWM), (b) $\mathrm{Me}^{201} \mathrm{Hg}$ photodegradation rate constants in DI water and Eveglades water with the addition of various complexation ligands.

of $\mathrm{Me}^{201} \mathrm{Hg}$ in HMW and LMW solutions, and unaltered Everglades water was then measured.

To determine whether the complexation of $\mathrm{MeHg}$ with DOM plays an important role in $\mathrm{MeHg}$ photodegradation, various competing ligands of $\mathrm{MeHg}$ were added to Everglades' or DI water containing $\mathrm{Me}^{201} \mathrm{Hg}\left(1.0 \mathrm{ng} \mathrm{L} \mathrm{L}^{-1}\right)$. These competing ligands included cysteine (CYS) $\left(10 \mathrm{mmol} \mathrm{L}^{-1}\right)$, and dithiothreitol (DTT) $\left(10 \mathrm{mmol} \mathrm{L}^{-1}\right)$. CYS and DTT were chosen as the candidate competing ligands due to their high affinity for $\mathrm{MeHg}$. Their complex stability constants with $\mathrm{MeHg}$ $(\log \mathrm{K})$ were 15.7, and 17.0, respectively and complexes of these ligands with $\mathrm{MeHg}$ were expected to be the major species of $\mathrm{MeHg}$ in Everglades water (99.99-100\%, Table S3, see SI for calculation). $\mathrm{MeHg}$ photodegradation rate constants in these treatments were then determined.

$\mathrm{MeHg}$ Photodegradation in Everglades Water in the Presence or Absence of $\mathrm{O}_{2}$ and the Effects of Scavenger Addition. To examine the importance of reactive oxygen species in $\mathrm{MeHg}$ photodegradation, $\mathrm{MeHg}$ photodegradation rate constants in Everglades water were measured with and without sparging with $\mathrm{N}_{2}$ or $\mathrm{O}_{2}$.

Scavengers for ${ }^{1} \mathrm{O}_{2}, \cdot \mathrm{OH},{ }^{3} \mathrm{DOM}^{*}$, or $\mathrm{e}^{-}$aq, were added to surface water to achieve a concentration of $0-200 \mathrm{mmol} \mathrm{L}^{-1}$ (SI Table S2 for concentration increments of each scavenger). $\mathrm{NaN}_{3}$ was chosen as the scavenger of ${ }^{1} \mathrm{O}_{2},{ }^{19}$ while isopropanol and dimethyl sulfoxide (DMSO) were selected as the scavengers of $\cdot \mathrm{OH}^{19,20}$ Isoprene was selected as the scavenger of ${ }^{3} \mathrm{DOM}^{*},{ }^{19,20,41}$ while $\mathrm{N}_{2} \mathrm{O}$ /isopropanol were used to scavenge $\mathrm{e}^{-}{ }_{\text {aq }}{ }^{42}$ Everglades water without adding any scavengers was included as a control. In addition, various concentrations of DMSO $\left(10^{-4}-100 \mathrm{mmol} \mathrm{L}^{-1}\right), \mathrm{NaN}_{3}(0-200$ mmol L $\left.{ }^{-1}\right)$, and isoprene $\left(0-20 \mathrm{mmol} \mathrm{L}^{-1}\right)$ were added to investigate the effects of scavenger concentrations on $\mathrm{MeHg}$ photodegradation. Triplicates (three separate bottles) were employed for each trial and control. $\mathrm{MeHg}$ photodegradation rate constants were measured using the method described above.

$\mathrm{MeHg}$ Degradation in the Presence of $\mathrm{MoO}_{4}{ }^{2-} / \mathrm{H}_{2} \mathrm{O}_{2}$ ( ${ }^{1} \mathrm{O}_{2}$ Generator). $\mathrm{Me}^{201} \mathrm{Hg}$ was spiked into $500 \mathrm{~mL}$ Everglades water to form a final concentration of $1.0 \mathrm{ng} \mathrm{L}^{-1}$ and the $\mathrm{pH}$ of the sample was adjusted to 10.4 with a $\mathrm{Na}_{2} \mathrm{CO}_{3}$ solution (10 mmol L $\left.{ }^{-1}\right) . \mathrm{MoO}_{4}{ }^{2-}$ was then added into the solution to form a final concentration of $2 \mathrm{mmol} \mathrm{L}-1 \cdot \mathrm{H}_{2} \mathrm{O}_{2}(38 \%)$ was then added into the solution five times $(2 \mathrm{~mL}$ every $2 \mathrm{~h})$ in $10 \mathrm{~h}$ every day. ${ }^{43,44}$ Samples were incubated in dark for 6 days and
$\mathrm{Me}^{201} \mathrm{Hg}$ concentrations on days $0,1,2,4$, and 6 were determined to calculate the degradation rate constants.

Data Analysis. Calculation of $\mathrm{MeHg}$ Photodegradation Rate Constants. A model based on second-order chemical kinetics was used to describe the photodegradation of $\mathrm{MeHg}$ in the water (eq 1). ${ }^{12,13}$ After integration of eq $1, \ln \left(C_{\mathrm{MeHg}}\right)_{t}$ could be simulated by $\ln \left(C_{\mathrm{MeHg}}\right)_{0}$ and cumulative PAR photon flux $(J)$, as described in eq 2 . The rate constant of $\mathrm{MeHg}$ degradation (with respect to photo flux), $k_{\mathrm{D}}$, was then obtained by linear regression of $\ln \left(C_{\mathrm{MeHg}}\right)_{\mathrm{t}}$ on $J$, using Origin (Version 6.0 for Windows, OriginLab Corp., Northampton, MA). The linear regression $\left(\mathrm{r}^{2}\right)$ and probability $(p)$ were employed to evaluate the quality of the fit (see SI Figure S6). A previously proposed method was adopted to adjust the attenuation of solar radiation by Teflon bottles. ${ }^{13}$ Values of $k_{\mathrm{D}}$ obtained with Teflon bottles were amended using the literature reported transmittance of Ultraviolet (UV)-B (66\%) and UV-A (82\%) through Teflon bottles. ${ }^{45}$

$$
\begin{aligned}
& \frac{d C_{\mathrm{MeHg}}}{d \mathrm{t}}=-k_{\mathrm{D}} \times C_{\mathrm{MeHg}} \times \mathrm{PAR} \\
& \ln \left(C_{\mathrm{MeHg}}\right)_{\mathrm{t}}=\ln \left(C_{\mathrm{MeHg}}\right)_{0}-k_{\mathrm{D}} \times J
\end{aligned}
$$

where $C_{\mathrm{MeHg}}$ is the concentration of $\mathrm{MeHg}\left(\mathrm{ng} \mathrm{L}^{-1}\right) ; k_{\mathrm{D}}$ is the rate constant of $\mathrm{MeHg}$ photodegradation $\left(\mathrm{m}^{2} \mathrm{E}^{-1}\right)$; PAR is the photosynthetically active radiation $\left(\mathrm{E} \mathrm{m}^{-2} \mathrm{~d}^{-1}\right)$; and $J$ is cumulative PAR photon flux $\left(\mathrm{E} \mathrm{m}^{-2}\right)$.

\section{RESULTS AND DISCUSSION}

Effects of MeHg-DOM Complexation on $\mathrm{MeHg}$ Photodegradation. Concentrations of $\mathrm{Me}^{201} \mathrm{Hg}$ decreased quickly in $>3000$ Da DOM solution (HWM), with a degradation rate constant of $17.6 \pm 1.1 \mathrm{E}^{-1} \mathrm{~m}^{2}$ (all presented as means \pm standard deviation), significantly higher ( $t$ test, $p<$ $0.01)$ than that in the unaltered Everglades water $(12.0 \pm 2.3$ $\mathrm{E}^{-1} \mathrm{~m}^{2}$, Figure 1a). As concentrations of inorganic ions, such as $\mathrm{Fe}, \mathrm{Mn}, \mathrm{NO}_{3}{ }^{-}$, and $\mathrm{NO}_{2}{ }^{-}$, in the concentrated HWM DOM solutions were decreased to $\sim 10^{-2}-10^{-3}$ times the original concentrations (SI Table S1), DOM present in the solution was likely the determining factor for the photodegradation of $\mathrm{MeHg}$ in HWM solution. Rapid degradation of $\mathrm{MeHg}$ was also observed in LWM $\left(21.1 \pm 2.3 \mathrm{E}^{-1} \mathrm{~m}^{2}\right)$ solution. The similar degradation rate constants in HWM and LWM suggested that both $>3000 \mathrm{Da}$ DOM and $<3000 \mathrm{Da}$ DOM could play an important role in $\mathrm{MeHg}$ photodegradation. Since the ion concentrations in LMW fraction were much higher than that in 

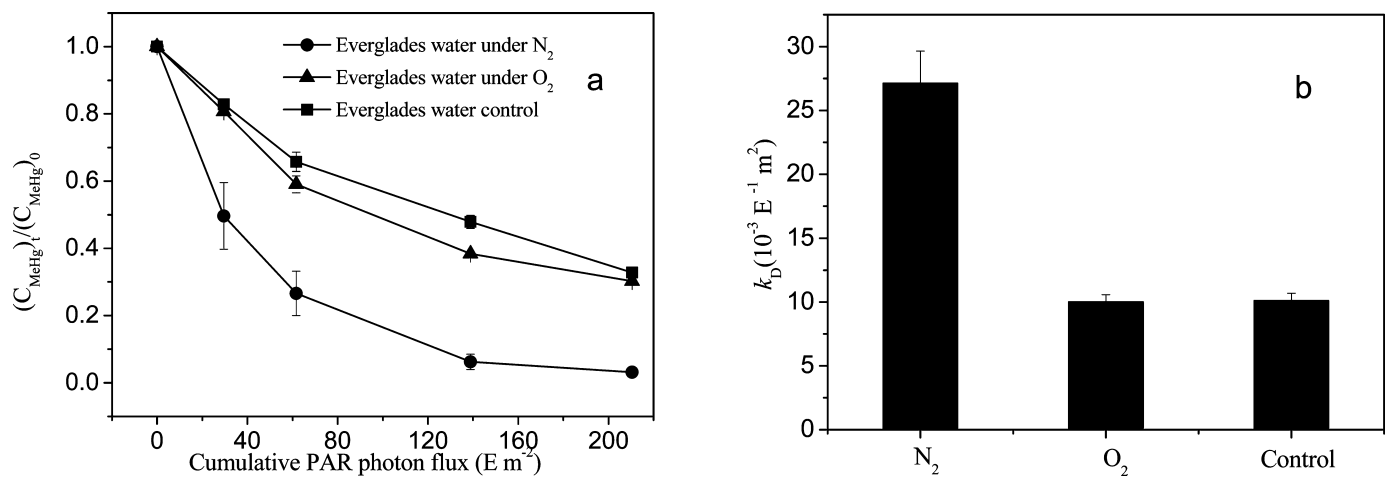

Figure 2. Influence of purging with $\mathrm{N}_{2}$ or $\mathrm{O}_{2}$ on the photodegradation of $\mathrm{MeHg}$ in Everglades water.
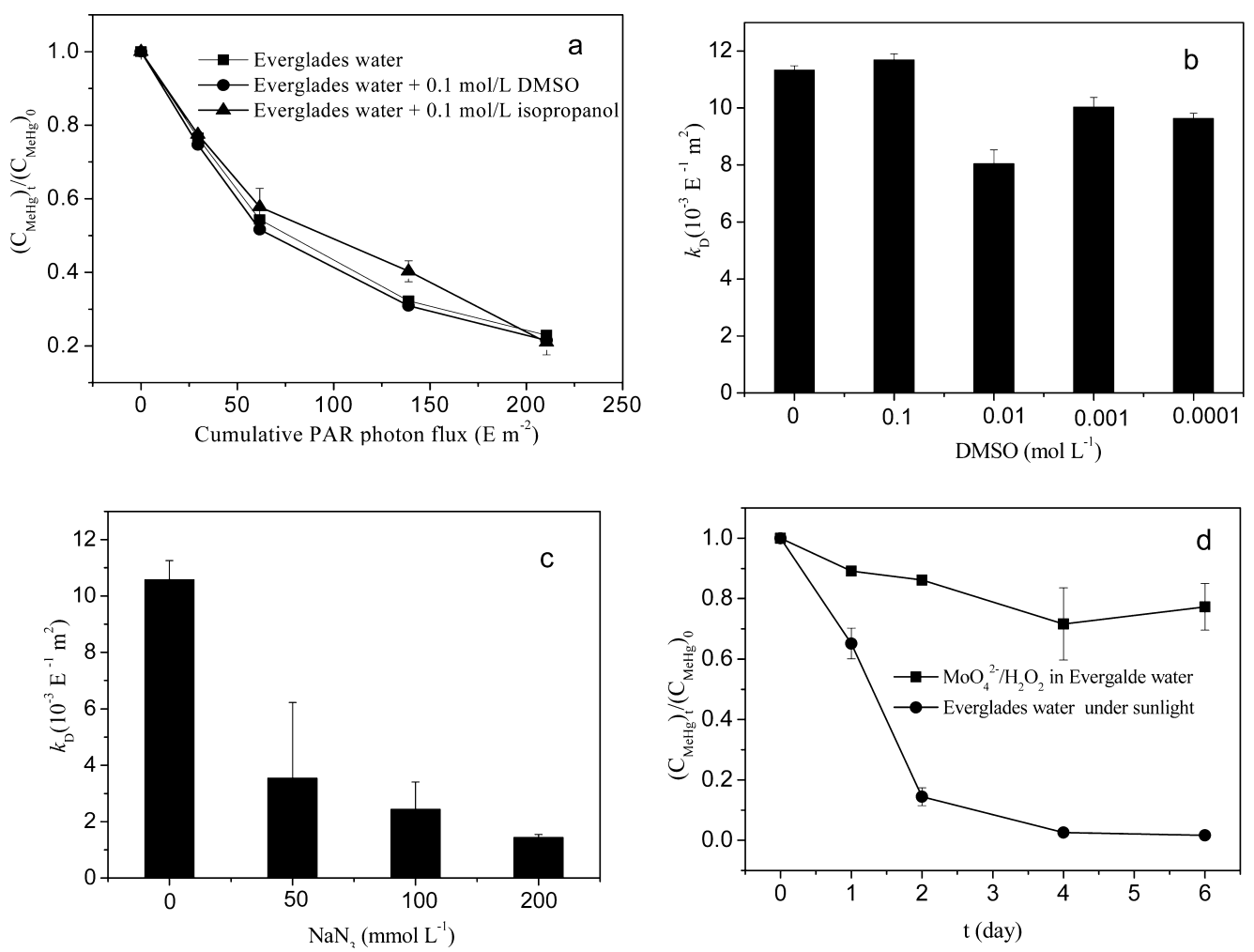

Figure 3. Effects of $\cdot \mathrm{OH}$ and ${ }^{1} \mathrm{O}_{2}$ on $\mathrm{MeHg}$ photodegradation in Everglades water. (a) $\mathrm{MeHg}$ photodegradation in Everglades water with and without the addition of $100 \mathrm{mmol} \mathrm{L}^{-1}$ isopropanol and DMSO, (b) $\mathrm{MeHg}$ photodegradation rate constants in Everglades water with various concentrations of DMSO, (c) $\mathrm{MeHg}$ photodegradation rate constants in Everglades water with various concentrations of $\mathrm{NaN}_{3}$, (d) $\mathrm{MeHg}^{2}$ photodegradation in Everglades water in the absence and presence of ${ }^{1} \mathrm{O}_{2}$ generated from $\mathrm{MoO}_{4}{ }^{2-} / \mathrm{H}_{2} \mathrm{O}_{2}$ system.

HMW fraction, the similar photodegradation rate constants in both fractions also indicate that various ions may not be the driving factors for $\mathrm{MeHg}$ photodegradation in Everglades surface water. During the 6-days of incubation, the bacterial populations may be changed. However, our previous study ${ }^{13}$ has demonstrated that the biotic degradation of $\mathrm{MeHg}$ does not play a significant role in $\mathrm{MeHg}$ degradation in Everglades surface waters. Thus, the changes in bacterial populations are not expected to affect the degradation of $\mathrm{MeHg}$.

The importance of $\mathrm{MeHg}-\mathrm{DOM}$ complexes in $\mathrm{MeHg}$ photodegradation was further examined by adding various competing ligands (CYS and DTT) in DI water and Everglades water. An appropriate competing ligand should have strong capacity of complexing $\mathrm{MeHg}$, while at the same time does not directly photodegrade $\mathrm{MeHg}$. Otherwise, it is impossible to differentiate the degradation of $\mathrm{MeHg}$ initiated by the competing ligands or by DOM. Consistent with most previous studies, ${ }^{19,20} \mathrm{MeHg}$ cannot be degraded in DI water (control) under ambient solar radiation (Figure 1b, SI Figure S2). Concentration of $\mathrm{MeHg}$ was observed to be quickly decreased in CYS solution, with a photodegradation rate constant of 8.50 $\pm 3.4 \mathrm{E}^{-1} \mathrm{~m}^{2}$ (Figure $\mathrm{lb}$ ). No significant degradation of $\mathrm{MeHg}$ was observed in the DI water containing DTT ( $t$ test, $p>0.1$ ). These results suggested that DTT is an appropriate ligand for studying the importance of $\mathrm{MeHg}-\mathrm{DOM}$ complexation.

In incubations without the addition of competing ligands, more than $97 \%$ of $\mathrm{MeHg}$ was calculated to be present in the form of $\mathrm{MeHg}-\mathrm{DOM}$ without the addition of competing ligands, while this ratio decreased to approximately $0 \%$ in the presence of DTT (see SI for calculations). The reduction in $\mathrm{MeHg}$ photodegradation rate constant could have been caused by the decomposition of $\mathrm{MeHg}-\mathrm{DOM}$ complexes, suggesting 

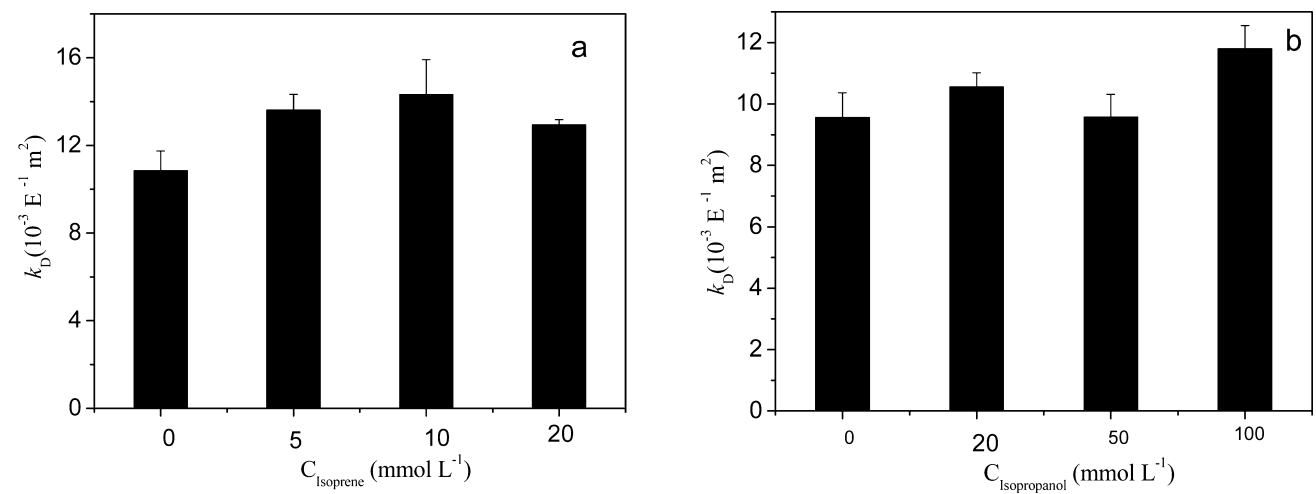

Figure 4. Effects of ${ }^{3} \mathrm{DOM}^{*}$ and $\mathrm{e}^{-}$aq scavengers on $\mathrm{MeHg}$ photodegradation in Everglades water. (a) MeHg photodegradation rate constants in Everglades water with various concentrations of isoprene (scavenger of ${ }^{3} \mathrm{DOM}^{*}$ ), (b) $\mathrm{MeHg}$ photodegradation in $\mathrm{N}_{2} \mathrm{O}$-saturated Everglades water with various concentrations of isopropanol (scavenger of $\mathrm{e}^{-}$aq).

that $\mathrm{DOM}$ was likely involved in $\mathrm{MeHg}$ photodegradation by forming $\mathrm{MeHg}-\mathrm{DOM}$ complexes in Everglades water. However, the addition of the competing ligands may also affect other parameters or processes that are involved in $\mathrm{MeHg}$ photodegradation, such as ionic strength, free radicals/reactive oxygen species, or bind with other metals (e.g., $\mathrm{Fe}^{3+}$ ). In addition, the photodegradation of $\mathrm{MeHg}-\mathrm{DOM}$ complexes may also be driven by free radicals/reactive oxygen species (pathway 2) (e.g., organic radicals, $\cdot \mathrm{OH}$ and $\left.{ }^{1} \mathrm{O}_{2}\right)^{17,19}$ according to the three possible mechanisms of $\mathrm{MeHg}$ photodegradation. $\mathrm{MeHg}$ photodegradation rate constants did not show significant difference (1-way ANOVA, $p>0.1$ ) under multiple concentrations of $\mathrm{NaCl}\left(0-1 \mathrm{~mol} \mathrm{~L}^{-1}\right)$ in Everglades water (SI Figure S2), indicating that the changes in ionic strength after adding various competing ligands should not have a great impact on $\mathrm{MeHg}$ photodegradation. Effects of various free radicals/reactive oxygen species, including $\cdot \mathrm{OH},{ }^{1} \mathrm{O}_{2},{ }^{3} \mathrm{DOM}^{*}$, $\mathrm{e}^{-}$aq, and organic radicals, were further studied to determine if these free radicals/reactive oxygen species were involved in the photodegradation of $\mathrm{MeHg}$ in Everglades water.

Effects of Free Radicals/Reactive Oxygen Species $(\cdot \mathrm{OH}$ and ${ }^{1} \mathrm{O}_{2}$ ) on $\mathrm{MeHg}$ Photodegradation. The rate constants of $\mathrm{MeHg}$ photodegradation $\left(k_{\mathrm{D}}\right)$ in unaltered Everglades water (control) and in Everglades water purged with $\mathrm{O}_{2}$ or $\mathrm{N}_{2}$ were measured. The photodegradation rate constant under $\mathrm{N}_{2}$ treatment $\left(27.15 \pm 2.50 \mathrm{E}^{-1} \mathrm{~m}^{2}\right)$ was about three times larger than that of the control $\left(10.13 \pm 0.56 \mathrm{E}^{-1} \mathrm{~m}^{2}\right)$ and $\mathrm{O}_{2}$ treatment $\left(10.02 \pm 0.56 \mathrm{E}^{-1} \mathrm{~m}^{2}\right.$ ) (Figure $2 \mathrm{a}$ and $\mathrm{b}$ ). As the production of free radicals/reactive oxygen species is expected to increase under oxic conditions and decrease under anoxic conditions, ${ }^{34,35}$ these results indicate that free radicals/reactive oxygen species may not play an important role in $\mathrm{MeHg}$ photodegradation in Everglades water. As this critical factor was often omitted in previous studies, the conclusion that free radicals/reactive oxygen species are the dominant factor ${ }^{19,20}$ may need further verification. Purging the solutions with $\mathrm{N}_{2}$ may also cause the loss of elemental mercury (assuming $\mathrm{Hg}^{0}$ is the product) in solution and consequently affect the equilibrium of $\mathrm{MeHg} / \mathrm{Hg}$ (II)/ $/ \mathrm{Hg}^{0}$. However, we observed that photodegradation of $\mathrm{MeHg}$ showed no difference for trials with or without purging with $\mathrm{O}_{2}$ (at a same flow rate as $\mathrm{N}_{2}$ ) ( $t$ test, $p>0.1$ ), indicating that the increase in $k_{\mathrm{D}}$ should not be attributed to the loss of $\mathrm{Hg}^{0}$ in solutions. The significant enhancement of $\mathrm{MeHg}$ photodegradation in treatment excluding $\mathrm{O}_{2}$ implies that $\mathrm{O}_{2}$ may serve as a scavenger of some intermediates of this process. To validate this finding, scavenger addition experiments were conducted to investigate the effects of $\cdot \mathrm{OH}$ and ${ }^{1} \mathrm{O}_{2}$ on $\mathrm{MeHg}$ photodegradation.

There were no significant differences between degradation of $\mathrm{MeHg}$ in the presence and absence of $0.1 \mathrm{~mol} \mathrm{~L}{ }^{-1} \mathrm{DMSO}$ or isopropanol (.OH scavenger) $(t$ test, $p>0.1$ ), downplaying the role played by $\cdot \mathrm{OH}$ in $\mathrm{MeHg}$ photodegradation (Figure 3a). To exclude the possible effects of scavenger concentration, multiple concentrations of DMSO, ranging from $10^{-4}-10^{-1} \mathrm{~mol} \mathrm{~L}^{-1}$, on $\mathrm{MeHg}$ photodegradation, were also examined (Figure $3 \mathrm{~b}$ ). Although 1-way ANOVA analysis showed that there were significant differences among the various levels of DMSO $(p<$ $0.01)$, the photodegradation rate constant in the presence of DMSO was comparable to that in the nonspiking water (73$103 \%)$. This result supported our conclusion that $\cdot \mathrm{OH}$ could not be the driver of $\mathrm{MeHg}$ photodegradation in Everglades water. The $\mathrm{MeHg}$ photodegradation rate constant significantly decreased (1-way ANOVA, $p<0.01$ ) for the treatment with 50-200 $\mathrm{mmol} \mathrm{L}^{-1} \mathrm{NaN}_{3}$, an ${ }^{1} \mathrm{O}_{2}$ scavenger (Figure 3c). This result was inconsistent with the results of $\mathrm{N}_{2} / \mathrm{O}_{2}$ purge experiments which showed that reactive oxygen species were not involved in $\mathrm{MeHg}$ photodegradation. To confirm the role of ${ }^{1} \mathrm{O}_{2}$ in the photodegradation of $\mathrm{MeHg}$, the degradation of $\mathrm{MeHg}$ in Everglades waters with ${ }^{1} \mathrm{O}_{2}$ generator, $\mathrm{MoO}_{4}{ }^{2-} / \mathrm{H}_{2} \mathrm{O}_{2}$ was compared with that under solar radiation (Figure $3 \mathrm{~d}$ ). Concentrations of ${ }^{1} \mathrm{O}_{2}$ in Everglades water with addition of $\mathrm{MoO}_{4}{ }^{2-} / \mathrm{H}_{2} \mathrm{O}_{2}\left(10^{-11} \mathrm{~mol} \mathrm{~L}{ }^{-1}\right.$, SI Table S6) was estimated to be approximately 100 times higher than that in Everglades water under solar radiation $\left(10^{-13} \mathrm{~mol} \mathrm{~L}^{-1}\right.$, SI Table S6). Therefore, the $\mathrm{MeHg}$ degradation rate constant in $\mathrm{MoO}_{4}{ }^{2-}$ / $\mathrm{H}_{2} \mathrm{O}_{2}$ system was expected to be much higher than that under solar radiation if ${ }^{1} \mathrm{O}_{2}$ drives $\mathrm{MeHg}$ photodegradation. However, the experiments showed that $\mathrm{MeHg}$ degradation rate constant in $\mathrm{MoO}_{4}{ }^{2-} / \mathrm{H}_{2} \mathrm{O}_{2}$ (Figure 3d) was very slow (approximately $10 \%$ of that in Everglades water under solar radiation), indicating that ${ }^{1} \mathrm{O}_{2}$ should not be a primary driver of $\mathrm{MeHg}$ photodegradation. Thus, the decrease in $\mathrm{MeHg}$ photodegradation rate constants in the presence of $\mathrm{NaN}_{3}$ is unlikely caused by the scavenging of ${ }^{1} \mathrm{O}_{2}$. As $\mathrm{N}_{3}{ }^{-}$has a mild affinity for mercury, with a $\log K_{\mathrm{Hg}-\mathrm{DOM}}$ of $7.74,{ }^{46}$ this decrease could be caused by the competition of $\mathrm{N}_{3}^{-}$with DOM for complexing $\mathrm{MeHg}$. We then conducted experiments to measure the percentage of $\mathrm{MeHg}$ complexed with $\mathrm{DOM}$ in the absence and presence of $\mathrm{NaN}_{3}\left(100 \mathrm{mmol} \mathrm{L}^{-1}\right)$ (SI Figure S3), using both dialysis bag and centrifuge-ultrafiltration. The results showed that $\mathrm{MeHg}$ compexed with DOM was dramatically decreased in the presence of $\mathrm{NaN}_{3}$. This finding suggested that 
$\mathrm{NaN}_{3}$ can also serve as a competing ligand of DOM for complexing with $\mathrm{MeHg}$. This result indicates that the previous conclusion that ${ }^{1} \mathrm{O}_{2}$ drives $\mathrm{MeHg}$ photodegradation ${ }^{19}$ does not fit the environments that $\mathrm{MeHg}-\mathrm{DOM}$ complexes are involved in this process, as the adopted scavenger of ${ }^{1} \mathrm{O}_{2}\left(\mathrm{NaN}_{3}\right)$ can inhibit $\mathrm{MeHg}$ photodegradation by both scavenging ${ }^{1} \mathrm{O}_{2}$ and competing with DOM for complexing with $\mathrm{MeHg}$.

Effects of ${ }^{3} \mathrm{DOM}^{*}, \mathrm{e}^{-}$aq and Organic Radicals on $\mathrm{MeHg}$ Photodegradation. In our current study, free radicals/ reactive oxygen species were found to play a minor role in the photodegradation of $\mathrm{MeHg}$ in Everglades water. In addition to $\cdot \mathrm{OH}$ and ${ }^{1} \mathrm{O}_{2}, \mathrm{e}^{-}{ }_{\text {aq, }}{ }^{28-30}{ }^{3} \mathrm{DOM}^{*},{ }^{26,27}$ can also exist in the aquatic environments and be involved in the photodegradation of different pollutants in water. ${ }^{3} \mathrm{DOM}^{*}$, a strong oxidant with the effective one-electron reduction potential of at least $1.36 \mathrm{~V}$, can be involved in photochemical processes in natural waters through direct reaction with pollutants or by sensitizing $\mathrm{O}_{2}$ to ${ }^{1} \mathrm{O}_{2} \cdot{ }^{47}$ As one of the strongest reducing agent with an effective one-electron reduction potential of $-2.84 \mathrm{~V}, \mathrm{e}^{-}$aq can be produced from sunlit DOM and has been proven to play an important role in the phototransformation of hydrophobic halogenated aromatic hydrocarbons. ${ }^{48,49}$ In addition, ${ }^{3} \mathrm{DOM}^{*}$ and $\mathrm{e}^{-}$aq prefer anoxic conditions. ${ }^{50}$ If $\mathrm{MeHg}$ photodegradation was driven by either of them, the increase in $\mathrm{MeHg}$ photodegradation rate constants under anoxic conditions could be explained.

The role of ${ }^{3} \mathrm{DOM}^{*}$ in $\mathrm{MeHg}$ photodegradation was examined by adding isoprene as the scavenger for ${ }^{3} \mathrm{DOM}^{*}$ (Figure 4a). The $\mathrm{MeHg}$ photodegradation rate constants did not decrease with the addition of isoprene $\left(0-20 \mathrm{mmol} \mathrm{L}^{-1}\right)$. $\mathrm{N}_{2} \mathrm{O}$ /isopropanol was chosen as the scavenging system for $\mathrm{e}^{-}$aq. In the $\mathrm{N}_{2} \mathrm{O}$ saturated Everglades water, the photodegradation of $\mathrm{MeHg}$ showed no significant difference (1-way ANOVA, $p>$ $0.1)$ for the trials with or without the addition of isopropanol $\left(0-100 \mathrm{mmol} \mathrm{L}^{-1}\right)$ (Figure $\left.4 \mathrm{~b}\right)$. These results indicate that both $\mathrm{e}^{-}$aq and ${ }^{3} \mathrm{DOM}^{*}$ are not the major reactive species inducing the photodegradation of $\mathrm{MeHg}$.

The role of organic radicals on $\mathrm{MeHg}$ photodegradation was evaluated by diluting Everglades water (Figure 5). Previous

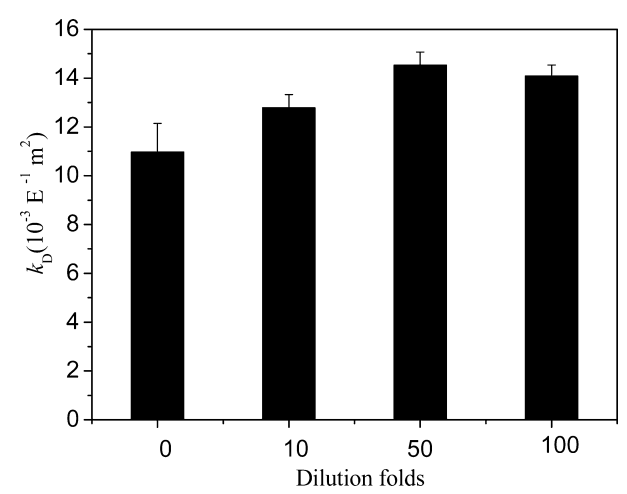

Figure 5. $\mathrm{Me}^{201} \mathrm{Hg}$ photodegradation rate constants in Everglades waters and diluted Everglades water (diluted 10, 50, and 100 folds).

studies on the transformation of $\mathrm{Fe}$ (II)/ $\mathrm{Fe}(\mathrm{III}), \mathrm{Cr}$ (VI)/ $\mathrm{Cr}(\mathrm{III})$ and $\mathrm{Hg}(\mathrm{II}) / \mathrm{Hg}^{0}$ induced by organic radicals showed that the transformation rate was dependent on the concentration of organic matter. ${ }^{51-53}$ The results in this study show that the photodegradation rate of $\mathrm{MeHg}$ did not decrease with increasing dilution of Everglades water DOM (up to 100 times), indicating that organic radicals may not be the intermediates driving $\mathrm{MeHg}$ photodegradation. However, it should be noted that diluting a natural water sample can change both the production and consumption rates of organic radicals. If the reaction orders were similar for both production and consumption reactions, the decrease in both processes would be similar, resulting in a comparable amount of organic radicals in the diluted waters. In water, DOM can absorb most UV radiation over a very short path length. The slightly increased $k_{\mathrm{D}}$ in diluted surface water could be attributed to the decreased concentrations of DOM.

Our data suggests that the role of free radicals/reactive oxygen species in photodegradation of $\mathrm{MeHg}$ in Everglades water is minimal. The decrease in $\mathrm{MeHg}$ photodegradation rates with the addition of competing ligands is expected to be caused by the decomposition of $\mathrm{MeHg}-\mathrm{DOM}$ complexes, rather than their effect on the factors that determine the production of free radicals/reactive oxygen species. By integrating all results obtained in this study and others, a mechanism involving direct photodegradation of $\mathrm{MeHg}-\mathrm{DOM}$ complexes via intramolecular charge transfer is proposed as the pathway of $\mathrm{MeHg}$ photodegradation in Everglades surface water. The proposed photodegradation of $\mathrm{MeHg}$ involves two steps: the excitation of $\mathrm{MeHg}-\mathrm{DOM}$ complexes under solar radiation, and the subsequent degradation of $\mathrm{MeHg}-\mathrm{DOM}$ complexes at an exited state (reactions 1 and 2). The $\mathrm{O}_{2}$ could deactivate $(\mathrm{MeHg}-\mathrm{DOM}) *$ (reaction 3 ), thus inhibiting the photodegradation of $\mathrm{MeHg}$. Although little is known about the possibility of direct photodegradation of $\mathrm{MeHg}-\mathrm{DOM}$ complexes, direct transfer of electrons from photosensitized DOM to $\mathrm{Hg}^{2+}$ within $\mathrm{Hg}^{2+}-\mathrm{DOM}$ complexes have been proposed as a possible pathways for $\mathrm{Hg}^{2+}$ photoreduction. ${ }^{54}$ DOM contains abundant electron-donating functional groups, such as hydroquinones or semiquinones, ${ }^{55,36}$ which can reduce various metal ions, for example, $\mathrm{Hg}^{2+57}$ and $\mathrm{Fe}^{3+} .58$ Based on the results of this study, we hypothesize that direct photodegradation of $\mathrm{MeHg}-\mathrm{DOM}$ complexes via $\mathrm{MeHg}-\mathrm{DOM}$ charge transfer may be the dominant pathway of $\mathrm{MeHg}$ photodegradation in Everglades water.

$$
\begin{aligned}
& \mathrm{MeHg}-\mathrm{DOM} \stackrel{h v}{\rightarrow}(\mathrm{MeHg}-\mathrm{DOM})^{*} \\
& (\mathrm{MeHg}-\mathrm{DOM})^{*} \\
& \quad \rightarrow \mathrm{MeHg} \text { degradation products }+\mathrm{DOM} \\
& (\mathrm{MeHg}-\mathrm{DOM})^{*}+\mathrm{O}_{2} \rightarrow(\mathrm{MeHg}-\mathrm{DOM})+\mathrm{O}_{2}
\end{aligned}
$$

Pathways of $\mathrm{MeHg}$ photodegradation varied in different aquatic ecosystems, as evidenced by inconsistent results reported in this study and previous studies. ${ }^{18}$ The variation of $\mathrm{MeHg}$ photodegradation pathway in different aquatic systems may be caused by differences in water chemistry, for example, concentration and chemical characteristics of DOM. For example, the ratio of $\mathrm{Fe} / \mathrm{DOC}$ (dissolved organic carbon) in an Arctic lake ${ }^{20}$ was approximately 20 times larger than that in Everglades, which may cause the different pathways of $\mathrm{MeHg}$ photodegradation in these two systems. A recent study showed that the mass independent fractionation (MIF) of $\mathrm{MeHg}$ by photodemethylation was significantly affected by the amount of reduced organic sulfur, ${ }^{59}$ implying that concentrations and characterization of DOM may also play an important role in determining the dominant pathway of $\mathrm{MeHg}$ photodegradation in natural water. In this study, $\mathrm{MeHg}$ was observed to be 
relatively stable in $\mathrm{NaN}_{3}$ solution and it can be quickly degraded in cysteine solution. This may be due to the variation of $\Delta E_{\mathrm{S}-\mathrm{T}}$ in these $\mathrm{MeHg}$ complexes. Theoretical calculations indicate that $\Delta E_{\mathrm{S}-\mathrm{T}}$ of $\mathrm{MeHg}-\mathrm{OH}$, and $\mathrm{MeHg}-\mathrm{Cl}$ (pathway 1) $\left(\Delta E_{\mathrm{S}-\mathrm{T}} 5.1-5.9 \mathrm{eV}^{22}\right)$ was higher than the high energy limit of the solar spectrum $\left(4.4 \mathrm{eV}^{23}\right)$. However, $\Delta E_{\mathrm{S} \text {-T }}$ of $\mathrm{MeHg}$ in the form of MeHg-organic sulfur compound could be decreased to $3.6 \mathrm{eV},{ }^{60}$ making the direct degradation of $\mathrm{MeHg}$-organic sulfur compound by solar radiation feasible. More reduced sulfurcontaining compounds can be formed in anoxic conditions to bind $\mathrm{MeHg}$. If thiol was the functional group dominating $\mathrm{MeHg}$ photodegradation, it could explain the higher photodegradation rates under anoxic conditions. In fact, several previous studies ${ }^{17,19}$ have provided experimental evidences on the possible importance of $\mathrm{MeHg}$-SR (thiol) interactions in DOM for the photodegradation of MeHg. Future work should be conducted to validate which functional groups in DOM dominate the $\mathrm{MeHg}$ photodegradation. Due to the differences in water chemistry in aquatic systems, for example, concentration levels of $\mathrm{DOM}, \mathrm{Fe}^{3+}, \mathrm{NO}_{3}{ }^{-}$, comparative studies on several systems with significant differences in aquatic chemistry (e.g., marine, wetland, and lake waters) should be conducted to determine the factors controlling the variation in the pathways of $\mathrm{MeHg}$ photodegradation.

\section{ASSOCIATED CONTENT}

\section{S Supporting Information}

Additional information as noted in the text. This material is available free of charge via the Internet at http://pubs.acs.org

\section{AUTHOR INFORMATION}

\section{Corresponding Author}

*Phone: 305-348-6210; fax: 305-348-3772; e-mail: cai@fiu.edu.

\section{Author Contributions}

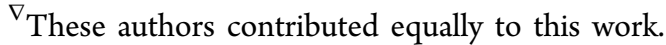

\section{Notes}

The authors declare no competing financial interest.

\section{ACKNOWLEDGMENTS}

This research was partially supported by the National Basic Research Program of China (2013CB430002), National Natural Science Foundation of China (21377120, 21120102040), and U.S. EPA Region 4, the National Park Service, Florida Department of Environmental Protection (FDEP) (CA H5297-05-008). This is contribution number 676 of the Southeast Environmental Research Center at Florida International University.

\section{REFERENCES}

(1) Julvez, J.; Debes, F.; Weihe, P.; Choi, A.; Grandjean, P. Sensitivity of continuous performance test (CPT) at age 14 years to developmental methylmercury exposure. Neurotoxicol. Teratol. 2010, 32 (6), 627-632.

(2) Mergler, D.; Anderson, H. A.; Chan, L. H. M.; Mahaffey, K. R.; Murray, M.; Sakamoto, M.; Stern, A. H. Methylmercury exposure and health effects in humans: A worldwide concern. Ambio 2007, 36 (1), 3-11.

(3) Burgess, N. M.; Meyer, M. W. Methylmercury exposure associated with reduced productivity in common loons. Ecotoxicology 2008, 17 (2), 83-91.

(4) Compeau, G. C.; Bartha, R. Sulfate-reducing bacteria: Principal methylators of mercury in anoxic estuarine sediment. Appl. Environ. Microbiol. 1985, 50 (2), 498-502.
(5) Kerin, E. J.; Gilmour, C. C.; Roden, E.; Suzuki, M. T.; Coates, J. D.; Mason, R. P. Mercury methylation by dissimilatory iron-reducing bacteria. Appl. Environ. Microbiol. 2006, 72 (12), 7919-7921.

(6) Lehnherr, I., St; Louis, V. L.; Hintelmann, H.; Kirk, J. L. Methylation of inorganic mercury in polar marine waters. Nat. Geosci. 2011, 4 (5), 298-302.

(7) Whalin, L.; Kim, E. H.; Mason, R. Factors influencing the oxidation, reduction, methylation and demethylation of mercury species in coastal waters. Mar. Chem. 2007, 107 (3), 278-294.

(8) Melnick, J. G.; Parkin, G. Cleaving mercury-alkyl bonds: A functional model for mercury detoxification by MerB. Science 2007, 317 (5835), 225-227.

(9) Dos Santos, H. F.; Duarte, H. A.; Sinisterra, R. D.; Mattos, S. V. D.; De Oliveira, L. F. C.; De Almeida, W. B. Quantum-mechanical study of the interaction of alpha-cyclodextrin with methyl mercury chloride. Chem. Phys. Lett. 2000, 319 (5-6), 569-575.

(10) Marvin-DiPasquale, M. C.; Oremland, R. S. Bacterial methylmercury degradation in Florida Everglades peat sediment. Environ. Sci. Technol. 1998, 32 (17), 2556-2563.

(11) Schaefer, J. K.; Yagi, J.; Reinfelder, J. R.; Cardona, T.; Ellickson, K. M.; Tel-Or, S.; Barkay, T. Role of the bacterial organomercury lyase (MerB) in controlling methylmercury accumulation in mercurycontaminated natural waters. Environ. Sci. Technol. 2004, 38 (16), 4304-4311.

(12) Hammerschmidt, C. R.; Fitzgerald, W. F. Photodecomposition of methylmercury in an arctic Alaskan lake. Environ. Sci. Technol. 2006, 40 (4), 1212-1216.

(13) Li, Y. B.; Mao, Y. X.; Liu, G. L.; Tachiev, G.; Roelant, D.; Feng, X. B.; Cai, Y. Degradation of methylmercury and its effects on mercury distribution and cycling in the Florida Everglades. Environ. Sci. Technol. 2010, 44 (17), 6661-6666.

(14) Sellers, P.; Kelly, C. A.; Rudd, J. W. M.; MacHutchon, A. R. Photodegradation of methylmercury in lakes. Nature 1996, 380 (6576), 694-697.

(15) Lehnherr, I.; St Louis, V. L.; Emmerton, C. A.; Barker, J. D.; Kirk, J. L. Methylmercury cycling in High Arctic wetland ponds: Sources and sinks. Environ. Sci. Technol. 2012, 46 (19), 10514-22.

(16) Sellers, P.; Kelly, C. A.; Rudd, J. W. M. Fluxes of methylmercury to the water column of a drainage lake: The relative importance of internal and external sources. Limnol. Oceanogr. 2001, 46 (3), 623631.

(17) Fernández-Gómez, C.; Drott, A.; Björn, E.; Díez, S.; Bayona, J. M.; Tesfalidet, S.; Lindfors, A.; Skyllberg, U. Towards universal wavelength-specific photodegradation rate constants for methyl mercury in humic waters, exemplified by a boreal lake-wetland gradient. Environ. Sci. Technol. 2013, 47 (12), 6279-6287.

(18) Black, F. J.; Poulin, B. A.; Flegal, A. R. Factors controlling the abiotic photo-degradation of monomethylmercury in surface waters. Geochim. Cosmochim. Acta 2012, 84, 492-507.

(19) Zhang, T.; Hsu-Kim, H. Photolytic degradation of methylmercury enhanced by binding to natural organic ligands. Nat. Geosci. 2010, 3 (7), 473-476.

(20) Hammerschmidt, C. R.; Fitzgerald, W. F. Iron-mediated photochemical decomposition of methylmercury in an Arctic Alaskan lake. Environ. Sci. Technol. 2010, 44 (16), 6138-6143.

(21) Lehnherr, I.; St. Louis, V. L. Importance of ultraviolet radiation in the photodemethylation of methylmercury in freshwater ecosystems. Environ. Sci. Technol. 2009, 43 (15), 5692-5698.

(22) Tossell, J. A. Theoretical study of the photodecomposition of methyl Hg complexes. J. Phys. Chem. A 1998, 102 (20), 3587-3591.

(23) Leighton, P. A. Photochemistry of Air Pollution; Academic Press: New York, 1961.

(24) Aguer, J. P.; Richard, C.; Andreux, F. Comparison of the photoinductive properties of commercial, synthetic and soil-extracted humic substances. J. Phys. Chem. A 1997, 103 (1-2), 163-168.

(25) Latch, D. E.; McNeill, K. Microheterogeneity of singlet oxygen distributions in irradiated humic acid solutions. Science 2006, 311 (5768), 1743-1747. 
(26) Canonica, S.; Hellrung, B.; Muller, P.; Wirz, J. Aqueous oxidation of phenylurea herbicides by triplet aromatic ketones. Environ. Sci. Technol. 2006, 40 (21), 6636-6641.

(27) Gerecke, A. C.; Canonica, S.; Muller, S. R.; Scharer, M.; Schwarzenbach, R. P. Quantification of dissolved natural organic matter (DOM) mediated phototransformation of phenylurea herbicides in lakes. Environ. Sci. Technol. 2001, 35 (19), 3915-3923.

(28) Kumamoto, Y.; Wang, J.; Fujiwara, K. Photoproduction and quenching of hydrated electrons from dissolved organic-matter in natural-waters. Bull. Chem. Soc. Jpn. 1994, 67 (3), 720-727.

(29) Wang, W.; Zafiriou, O. C.; Chan, I. Y.; Zepp, R. G.; Blough, N. $\mathrm{V}$. Production of hydrated electrons from photoionization of dissolved organic matter in natural waters. Environ. Sci. Technol. 2007, 41 (5), $1601-1607$.

(30) Zepp, R. G.; Braun, A. M.; Hoigne, J.; Leenheer, J. A. Photoproduction of hydrated electrons from natural organic solutes in aquatic environments. Environ. Sci. Technol. 1987, 21 (5), 485-490.

(31) Vione, D.; Falletti, G.; Maurino, V.; Minero, C.; Pelizzetti, E.; Malandrino, M.; Ajassa, R.; Olariu, R. I.; Arsene, C. Sources and sinks of hydroxyl radicals upon irradiation of natural water samples. Environ. Sci. Technol. 2006, 40 (12), 3775-3781.

(32) Mopper, K.; Zhou, X. L. Hydroxyl radical photoproduction in the sea and its potential impact on marine processes. Science 1990, 250 (4981), 661-664.

(33) Ravichandran, M. Interactions between mercury and dissolved organic matter-A review. Chemosphere 2004, 55 (3), 319-331.

(34) Kong, L.; Zepp, R. G. Production and consumption of reactive oxygen species by fullerenes. Environ. Toxicol. Chem. 2012, 31 (1), 136-143.

(35) Xu, H.; Cooper, W. J.; Jung, J.; Song, W. Photosensitized degradation of amoxicillin in natural organic matter isolate solutions. Water Res. 2011, 45 (2), 632-638.

(36) Cleckner, L. B.; Gilmour, C. C.; Hurley, J. P.; Krabbenhoft, D. P. Mercury methylation in periphyton of the Florida Everglades. Limnol. Oceanogr. 1999, 44 (7), 1815-1825.

(37) Gilmour, C. C.; Riedel, G. S.; Ederington, M. C.; Bell, J. T.; Benoit, J. M.; Gill, G. A.; Stordal, M. C. Methylmercury concentrations and production rates across a trophic gradient in the northern Everglades. Biogeochemistry 1998, 40, 327-345.

(38) Vaithiyanathan, P.; Richardson, C. J.; Kavanaugh, R. G.; Craft, C. B.; Barkay, T. Relationships of eutrophication to the distribution of mercury and to the potential for methylmercury production in the peat soils of the everglades. Environ. Sci. Technol. 1996, 30 (8), 2591-2597.

(39) Stober, Q. J.; Thornton, K.; Jones, R.; Richards, J.; Ivey, C.; Welch, R.; Madden, M.; Trexler, J.; Gaiser, E.; Scheidt, D.; Rathbun, S. South Florida Ecosystem Assessment: Phase I/II(Technical Report)Everglades Stressor Interactions: Hydropatterns, Eutrophication, Habitat Alteration, and Mercury Contamination; U.S. EPA Region 4: Athens, GA, 2001.

(40) Li, Y.; Yin, Y.; Liu, G.; Tachiev, G.; Roelant, D.; Jiang, G.; Cai, Y. Estimation of the major source and sink of methylmercury in the Florida Everglades. Environ. Sci. Technol. 2012, 46 (11), 5885-5893.

(41) Zepp, R. G.; Schlotzhauer, P. F.; Sink, R. M. Photosensitized transformations involving electronic-energy transfer in naturalwaters-Role of humic substances. Environ. Sci. Technol. 1985, 19 (1), 74-81.

(42) Thomas-Smith, T. E.; Blough, N. V. Photoproduction of hydrated electron from constituents of natural waters. Environ. Sci. Technol. 2001, 35 (13), 2721-2726.

(43) Aubry, J. M.; Cazin, B. Chemical sources of singlet oxygen. 2. Quantitative generation of singlet oxygen from hydrogen peroxide disproportionation catalyzed by molybdate ions. Inorg. Chem. 1988, 27 (12), 2013-2014.

(44) Tai, C.; Jiang, G. B. Dechlorination and destruction of 2,4,6trichlorophenol and pentachlorophenol using hydrogen peroxide as the oxidant catalyzed by molybdate ions under basic condition. Chemosphere 2005, 59 (3), 321-326.
(45) Amyot, M.; Lean, D.; Mierle, G. Photochemical formation of volatile mercury in high Arctic lakes. Environ. Toxicol. Chem. 1997, 16 (10), 2054-2063.

(46) Hepler, L. G.; Olofsson, G. Mercury. Thermodynamic properties, chemical equilibriums, and standard potentials. Chem. Rev. 1975, 75 (5), 585-602.

(47) Canonica, S.; Jans, U.; Stemmler, K.; Hoigne, J. Transformation kinetics of phenols in water: Photosensitization by dissolved natural organic material and aromatic ketones. Environ. Sci. Technol. 1995, 29 (7), 1822-1831.

(48) Burns, S. E.; Hassett, J. P.; Rossi, M. V. Binding effects on humic-mediated photoreaction: Intrahumic dechlorination of mirex in water. Environ. Sci. Technol. 1996, 30 (10), 2934-2941.

(49) Burns, S. E.; Hassett, J. P.; Rossi, M. V. Mechanistic implications of the intrahumic dechlorination of mirex. Environ. Sci. Technol. 1997, 31 (5), 1365-1371.

(50) Richard, C.; Canonica, S. Aquatic phototransformation of organic contaminants induced by coloured dissolved natural organic matter. Handb. Environ. Chem. 2005 2, 299-323.

(51) He, F.; Zheng, W.; Liang, L. Y.; Gu, B. H. Mercury photolytic transformation affected by low-molecular-weight natural organics in water. Sci. Total Environ. 2012, 416, 429-435.

(52) Pozdnyakov, I. P.; Kel, O. V.; Plyusnin, V. F.; Grivin, V. P.; Bazhin, N. M. New insight into photochemistry of ferrioxalate. J. Phys. Chem. A 2008, 112 (36), 8316-8322.

(53) Abida, O.; Mailhot, G.; Mestankova, H.; Litter, M.; Bolte, M. Photoinduced reduction of chromium(VI) by iron aminopolycarboxylate complex (FeNTA). Photochem. Photobiol. Sci. 2010, 9 (6), 823829.

(54) Allard, B.; Arsenie, I. Abiotic reduction of mercury by humic substances in aquatic system-an important process for the mercury cycle. Water, Air, Soil Pollut. 1991, 56, 457-464.

(55) Ratasuk, N.; Nanny, M. A. Characterization and quantification of reversible redox sites in humic substances. Environ. Sci. Technol. 2007, 41 (22), 7844-7850.

(56) Kappler, A.; Benz, M.; Schink, B.; Brune, A. Electron shuttling via humic acids in microbial iron(III) reduction in a freshwater sediment. FEMS Microbiol. Ecol. 2004, 47 (1), 85-92.

(57) Zheng, W.; Liang, L.; Gu, B. Mercury reduction and oxidation by reduced natural organic matter in anoxic environments. Environ. Sci. Technol. 2012, 46 (1), 292-299.

(58) Barbeau, K. Photochemistry of organic iron(III) complexing ligands in oceanic systems. Photochem. Photobiol. 2006, 82 (6), 15051516.

(59) Chandan, P. Mercury Isotope Fractionation during Aqueous Photoreduction of Methylmercury in Presence of Different Types and Amounts of Dissolved Organic Matter; University of Toronto: Toronto, 2011.

(60) Yoon, S.-J.; Diener, L. M.; Bloom, P. R.; Nater, E. A.; Bleam, W. F. X-ray absorption studies of $\mathrm{CH}_{3} \mathrm{Hg}^{+}$-binding sites in humic substances. Geochim. Cosmochim. Acta 2005, 69 (5), 1111-1121. 